\section{Occupational Rhinitis Due to Inhaled Locust Bean Gum: Cross-Reactivity With Legumes and Nuts}

\author{
Vázquez de la Torre $\mathrm{M}^{1}$, Haroun-Díaz E ${ }^{1}$, Blanca-López $\mathrm{N}^{1}$, \\ Somoza $\mathrm{ML}^{1}$, Ruano $\mathrm{FJ}^{1}$, Garcimartín $\mathrm{M}^{1}$, Pérez-Alzate $\mathrm{D}^{1}$, \\ Prieto-Moreno $\mathrm{A}^{1}$, Bartolomé $\mathrm{B}^{2}$, Canto $\mathrm{G}^{1}$ \\ ${ }^{1}$ Allergy Service, Infanta Leonor University Hospital, Madrid, Spain \\ ${ }^{2} I+D$ Department, Roxall, Bilbao, Spain
}

J Investig Allergol Clin Immunol 2020; Vol. 30(5): 360-362 doi: 10.18176/jiaci.0503

Key words: Locust bean gum. Occupational rhinitis. Cross-reactivity. Legumes. Tree nuts.

Palabras clave: Goma garrofín. Rinitis ocupacional. Reactividad cruzada. Legumbres. Frutos secos.

Food allergy affects $11.4 \%$ of patients who visit the allergologist for the first time in Spain, and there is increasing evidence of a rise in prevalence. Tree nuts are the second cause of food allergy in Spain (28.4\% of patients); in contrast, legume allergy is uncommon ( $3 \%$ of patients) [1].

The carob tree (Ceratonia siliqua $L$ ) belongs to the Leguminosae family and is widely cultivated in the Mediterranean area. Locust bean gum (LBG) is a vegetable gum that is extracted from carob tree seed (CTS) and used mainly in food technology as a thickening and gelling agent. Commercial LBG (E410) is a powder composed of galactomannan $(80 \%)$, proteins $(5 \%-6 \%)$, fat $(0.5 \%-0.9 \%)$, and fibers $(0.8 \%-1 \%)$ that are derived from the endosperm of the CTS [2].

Legume allergens encompass the cupin, prolamin, PR-10, and lipid transfer protein families. Previous studies show that $11 \mathrm{~S}$ globulins are involved in cross-reactivity between legumes (peanut and soybean), tree nuts (almond, hazelnut, pistachio, and walnut), and seeds (mustard seeds) [3]. We report the case of a 44-year-old woman with a history of rhinoconjunctivitis to pollen who had worked in an ice cream factory for 9 years. She had a 2-year history of ocular and nasal itching, rhinorrhea, nasal congestion, and sneezing every time she handled Cremodan SL29, a powder used as a stabilizer in ice cream. When working, she wore a safety mask and protective eyewear. Her duties included measuring the powder and mixing it with sugar. Her symptoms appeared during the first 5 minutes after handling Cremodan SL29 and disappeared within 24 hours of taking intranasal budesonide and oral loratadine. She reported no bronchial symptoms and was able to ingest the ice cream that she had prepared with Cremodan SL29. She tolerated handling and ingestion of guar gum.

According to the manufacturer, Cremodan SL29 contains LBG (E410), dextrose, milk proteins, gelatin, pectin (E440), and carrageenan (E407).

One year after her initial symptoms presented, she developed pharyngeal itching, eyelid angioedema, and dyspnea when ingesting chickpea. She also experienced cough after oral intake of almonds, pistachio, and sunflower seeds. Since then, she has avoided legumes (except peas and green beans, which she tolerates) and tree nuts.

Pulmonary function tests revealed normal spirometry values; the result of a nonspecific methacholine bronchial challenge was negative.

Prick-prick testing with Cremodan SL29 was positive $(13 \times 9 \mathrm{~mm})$, and skin prick tests (SPTs) were positive to CTS extract $(8 \times 7 \mathrm{~mm})$ and LBG $(4 \times 4 \mathrm{~mm})$. SPTs to dextrose, milk protein, gelatin, pectin, and carrageenan were negative.

SPTs to legume extracts (Roxall) were positive for chickpea $(4 \times 4 \mathrm{~mm})$, soybean $(6 \times 4 \mathrm{~mm})$, and lentil $(4 \times 3 \mathrm{~mm})$ and negative for peanut, pea, and white, red, and green bean. A prick-prick test with soybean was positive $(5 \times 5 \mathrm{~mm})$.

The results of SPT with tree nut extract (Roxall) were negative, although the prick-prick test showed positive results for walnut $(9 \times 4 \mathrm{~mm})$, almond $(7 \times 7 \mathrm{~mm})$, cashew $(4 \times 3 \mathrm{~mm})$, pistachio $(7 \times 4 \mathrm{~mm})$, pine nut $(5 \times 4 \mathrm{~mm})$, and sunflower seeds $(6 \times 7 \mathrm{~mm})$. The result of prick-prick testing with hazelnut was negative.

Determination of serum-specific IgE (IMMULITE 2000/ Xpi, Siemens) showed the following values for legume and tree nut extracts: chickpea, $1.70 \mathrm{kU}_{\mathrm{A}} / \mathrm{L}$; soybean, $0.99 \mathrm{kU}_{\mathrm{A}} / \mathrm{L}$; lentil, $1.07 \mathrm{kU}_{\mathrm{A}} / \mathrm{L}$; peanut, $0.28 \mathrm{kU}_{\mathrm{A}} / \mathrm{L}$; pea, $1.46 \mathrm{kU}_{\mathrm{A}} / \mathrm{L}$; red bean, $0.58 \mathrm{kU}_{\mathrm{A}} / \mathrm{L}$; green bean, $0.14 \mathrm{kU}_{\mathrm{A}} / \mathrm{L}$; walnut, $0.22 \mathrm{kU}_{\mathrm{A}} / \mathrm{L}$; almond, $1.31 \mathrm{kU}_{\mathrm{A}} / \mathrm{L}$; cashew, $0.24 \mathrm{kU}_{\mathrm{A}} / \mathrm{L}$; and pistachio, $0.18 \mathrm{kU}_{\mathrm{A}} / \mathrm{L}$. Specific IgE to white bean, pine nut, and hazelnut were negative $\left(<0.10 \mathrm{kU}_{\mathrm{A}} / \mathrm{L}\right)$. Total $\operatorname{IgE}$ was $399 \mathrm{IU} / \mathrm{mL}$.

A single-blind oral challenge performed with cooked white bean resulted in intense oral itching and cough 30 minutes after the second dose (3 pieces).

ACTS extract was prepared by homogenization $(18 \% \mathrm{wt} / \mathrm{vol})$ in phosphate-buffered saline $(50 \mathrm{mM}$ phosphate buffer, 100 $\mathrm{mM} \mathrm{NaCl}, \mathrm{pH} 7.5$ ) for 4 hours at room temperature, followed by dialyzation and lyophilization. The Bradford method was used to assess the protein percentage in the extracts [4]. Sodium dodecyl sulphate polyacrylamide gel electrophoresis (SDS-PAGE) immunoblotting was performed to study the molecular mass of the IgE-binding bands in the Cremodan SL29 sample (5\% protein), LBG powder (1.6\% protein), and CTS extract (15\% protein), showing a similar IgE-binding band profile. Bands of $69,55,50,35,34,28,22$, and $19.5 \mathrm{kDa}$ were detected (Figure, I).

Cross-reactivity studies were performed with chickpea and almond, as these showed the highest levels of serumspecific IgE, and the patient reported symptoms after ingestion. SDS-PAGE immunoblotting inhibition studies revealed complete inhibition of $\operatorname{IgE}$ binding in the LBG sample and CTS extract with Cremodan SL29 and extracts from chickpea (50\% protein) and almond ( $70 \%$ protein). Cremodan SL29 completely inhibited IgE binding with chickpea extract and partial inhibition with almond extract (Figure, II). We hypothesized that the patient was sensitized to the remaining CTS proteins present in the LBG sample. The paucity of published data in this area prevents us from speculating about the identity of the IgE-reactive CTS proteins detected. However, the molecular masses of the chickpea and almond proteins (Figure, II) that cross-react 


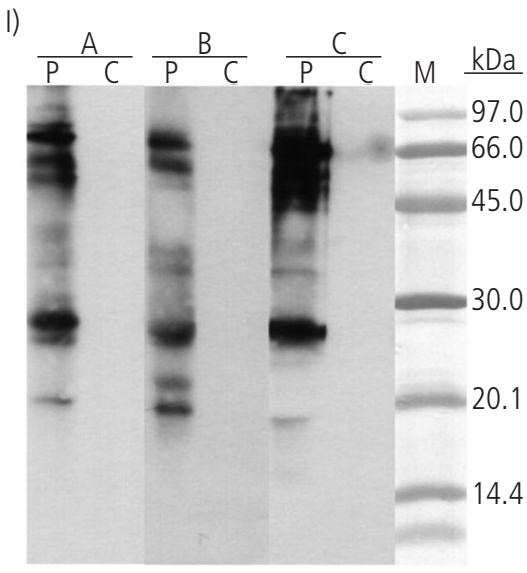

II)

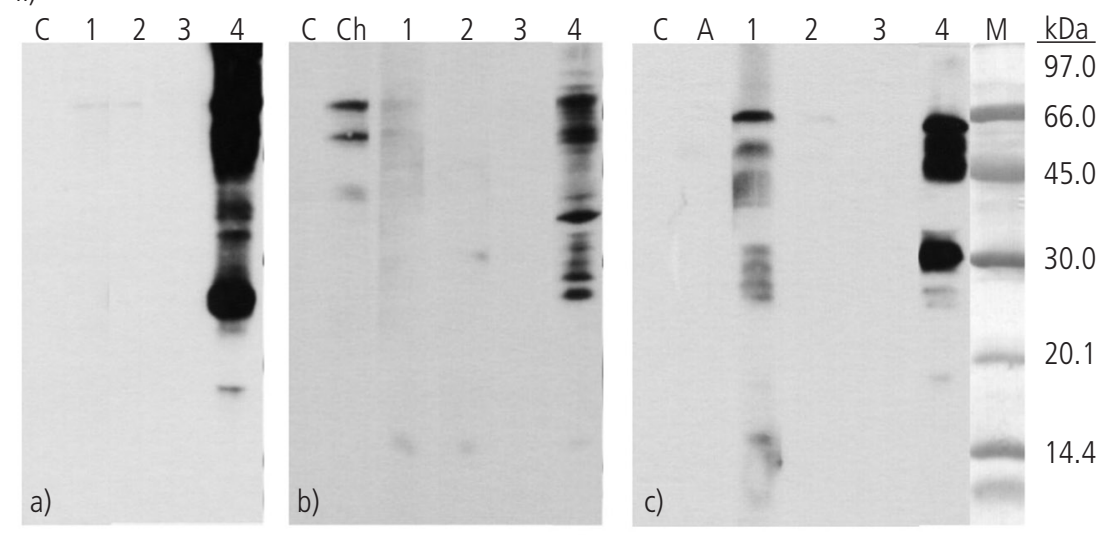

Figure. I, SDS-PAGE immunoblotting assay: A, locust bean gum; B, carob tree seed extract; C, Cremodan SL29. Lane P, patient serum; Lane C, control serum (pool of sera from nonatopic individuals). II, SDS-PAGE immunoblotting-inhibition.

Solid phase: a, Cremodan SL29; b, chickpea extract; c, almond extract.

Lane $C$, control serum (pool of sera from nonatopic individuals).

Lanes Ch, $A$, and 1-4: Patient serum preincubated with the following: $C h$, chickpea extract (400 $\mu \mathrm{g}$ protein/mL; inhibition positive control); $\mathrm{A}$, almond extract (450 $\mu \mathrm{g}$ protein $/ \mathrm{mL}$; inhibition positive control); 1, Cremodan SL29 (50 $\mu \mathrm{g}$ protein $/ \mathrm{mL}) ; 2$, locust bean gum (5 $\mu \mathrm{g}$ protein $/ \mathrm{mL}) ; 3$, carob tree seed extract (150 $\mu \mathrm{g}$ protein/mL); 4, lamb extract. Lane M, molecular mass standard.

with them lead us to suppose that they could belong to $11 \mathrm{~S}$ globulin type (cupin superfamily) $[5,6]$. The molecular masses of some of the CTS IgE-reactive proteins detected $(67 \mathrm{kDa}, 55 \mathrm{kDa}, 28 \mathrm{kDa})$ are similar to some of those observed by Alarcon et al [7].

Of all the cases of LBG sensitization reported to date, few address occupational exposure in the food industry [8-9]. None of the work-related cases involved reactions after the ingestion of legumes or tree nuts.

As LBG is obtained from CTS, a member of the Leguminosae family, some authors studied the cross-reactivity between LBG powder and legume proteins. Fiocchi et al [10] reported sensitization to carob by means of SPT and in vitro testing in peanut-allergic individuals, all of whom tolerated cooked carob. Alarcón et al [7] observed sensitization to legume and tree nut (positive SPT and specific IgE) in a patient with a clinically relevant allergy to LBG (urticaria after ingestion of caramel containing LBG), although this patient tolerated ingestion of legumes and tree nuts.

We present a case of occupational IgE-mediated sensitization to inhaled proteins in an LBG sample with clinical consequences for ingestion of legume. To our knowledge, this is the first report of a clinically relevant allergy to carob gum, legumes, and tree nuts due to cross-reactivity between their proteins.

\section{Funding}

The authors declare that no funding was received for the present study.

\section{Conflicts of Interest}

The authors declare that they have no conflicts of interest.

\section{References}

1. Ojeda P, Sastre J, Olaguibel JM, Chivato T; investigators participating in the National Survey of the Spanish Society of Allergology and Clinical Immunology Alergológica 2015. Alergológica 2015: A National Survey on Allergic Diseases in the Adult Spanish Population. J Investig Allergol Clin Immunol. 2018 Jun;28(3):151-1642.

2. Barak S, Mudgil D. Locust bean gum: Processing, properties and food applications-A review. Int J Biol Macromol. 2014;66:74-80.

3. Sirvent $S$, Akotenou M, Cuesta-Herranz J, Vereda A, Rodríguez $R$, Villalba $M$, et al. The $11 \mathrm{~S}$ globulin Sin a 2 from yellow mustard seeds shows IgE cross-reactivity with homologous counterparts from tree nuts and peanut. Clin Transl Allergy. 2012 Dec 11;2(1):23.

4. Bradford MM. A rapid and sensitive method for the quantification of microgram quantities of protein utilizing the principles of protein-dye-binding. Anal Biochem. 1976;72:248-54.

5. Willison LN, Tripathi P, Sharma G, Teuber SS, Sathe SK, Roux KH. Cloning, Expression and Patient IgE Reactivity of Recombinant Pru du 6, an 115 Globulin from Almond. Int Arch Allergy Immunol. 2011;156(3):267-81.

6. Chang YW, Alli I, Konishi Y, Ziomek E. Characterization of protein fractions from chickpea (Cicer arietinum L.) and oat (Avena sativa L.) seeds using proteomic techniques. Food Res Int. 2011;44:3094-104.

7. Alarcon E, del Pozo MD, Bartolome B, Navarro B, Escudero R, Gonzalez I, et al. Urticaria and angioedema due to ingestion of carob gum: a case report. J Investig Allergol Clin Immunol. 2011;21(1):77-8. 
8. Scoditti A, Peluso P, Pezzuto R, Giordano T, Melica A. Asthma to carob bean flour. Ann Allergy Asthma Immunol. 1996;77(1):81.

9. Hawley $B$, Cummings $K J$, Mohammed $M$, Dimmock $A E$, Bascom R. Allergic sinusitis and severe asthma caused by occupational exposure to locust bean gum: Case report. Am J Ind Med. 2017;60(7):658-63.

10. Fiocchi A, Restani P, Travaini M, Decet E, Gaiaschi A, Bernardo $L$, et al. Carob is not allergenic in peanut-allergic subjects. Clin Exp Allergy. 1999;29(3):402-6.

Manuscript received October 14, 2019; accepted for publication February 24, 2020.

María Vázquez de la Torre Allergy Service Infanta Leonor University Hospital

Av. Gran Vía del Este, 80 28031 Madrid, Spain

E-mail: mvazquezt@salud.madrid.org 